\title{
Long-term records of trace metal content of western Mediterranean seagrass (Posidonia oceanica) meadows: Natural and anthropogenic contributions
}

\author{
Antonio Tovar-Sánchez, ${ }^{1}$ Juan Serón, ${ }^{1}$ Núria Marbà, ${ }^{1}$ Jesús M. Arrieta, ${ }^{1}$ \\ and Carlos M. Duarte ${ }^{1}$ \\ Received 11 June 2009; revised 24 October 2009; accepted 9 December 2009; published 24 April 2010.
}

[1] We discuss $\mathrm{Al}, \mathrm{Ag}, \mathrm{Cd}, \mathrm{Co}, \mathrm{Cr}, \mathrm{Cu}, \mathrm{Fe}, \mathrm{Mn}, \mathrm{Ni}, \mathrm{Pb}$, and $\mathrm{Zn}$ contents in seagrass Posidonia oceanica rhizomes from the Balearic Archipelago for the last 3 decades. Time series of metal concentration in $P$. oceanica were measured by dating rhizomes using retrospective procedures. The highest concentrations of $\mathrm{Al}\left(174.73 \mu \mathrm{g} \mathrm{g}^{-1}\right), \mathrm{Cd}(3.56 \mu \mathrm{g}$ $\left.\mathrm{g}^{-1}\right), \mathrm{Cr}\left(1.34 \mu \mathrm{g} \mathrm{g}^{-1}\right), \mathrm{Cu}\left(32.15 \mu \mathrm{g} \mathrm{g}^{-1}\right), \mathrm{Pb}\left(8.51 \mu \mathrm{g} \mathrm{g}^{-1}\right)$, and $\mathrm{Zn}\left(107.14 \mu \mathrm{g} \mathrm{g}^{-1}\right)$ were measured in meadows located around the largest and most densely populated island (Mallorca Island). There was a general tendency for Ag concentration to decrease with time (up to $80 \%$ from 1990 to 2005 in sample from Mallorca Island), which could be attributed to a reduction of the anthropogenic sources. Nickel and $\mathrm{Zn}$ concentrations were the unique elements that showed a consistent temporal trend in all samples, increasing their concentrations since year 1996 at all studied stations; this trend matched with the time series of UV-absorbing aerosols particles in the air (i.e., aerosols index) over the Mediterranean region $\left(\mathrm{r}^{2}: 0.78, \mathrm{p}<0.001\right.$ for Cabrera Island), suggesting that $P$. oceanica could be an efficient recorder of dust events. A comparison of enrichment factors in rhizomes relative to average crustal material indicates that suspended aerosol is also the most likely source for $\mathrm{Cr}$ and $\mathrm{Fe}$ to $P$. oceanica.

Citation: Tovar-Sánchez, A., J. Serón, N. Marbà, J. M. Arrieta, and C. M. Duarte (2010), Long-term records of trace metal content of western Mediterranean seagrass (Posidonia oceanica) meadows: Natural and anthropogenic contributions, J. Geophys. Res., 115, G02006, doi:10.1029/2009JG001076.

\section{Introduction}

[2] Trace metals occur naturally in the ocean, mostly as colloids or absorbed onto organic and inorganic suspended particles, and tend to accumulate in living organisms and bottom sediments. While some trace metals, such as $\mathrm{Cd}, \mathrm{Co}$, $\mathrm{Cu}, \mathrm{Fe}, \mathrm{Mn}, \mathrm{Ni}$ and $\mathrm{Zn}$ play a key biological role in the sea, regulating biochemical function in marine organism, they may be present in excess and, along with other metals (e.g., $\mathrm{As}, \mathrm{Pb}$ ), can negatively affect ecosystem health [Fraústo da Silva and Williams, 1991; Morel and Price, 2003]. Identification of the contribution of natural and/or anthropogenic main sources and pathways of trace metals entering the sea, are crucial for understanding the biogeochemical processes occurring in the coastal waters, and to effectively design and implement polices to improve the health of coastal systems.

[3] The coastal zone of the Mediterranean Sea is subject to the input of trace metal mobilized by human activities such as urbanization, tourism, agriculture, aquaculture, industries, marine traffic, etc. For example, while some metals

\footnotetext{
${ }^{1}$ Department of Global Change Research, Instituto Mediterráneo de Estudios Avanzados, Esporles, Spain.

Copyright 2010 by the American Geophysical Union. 0148-0227/10/2009JG001076
}

discharged to water in the Mediterranean could be from industrial origin, such as leather and leather products $(\mathrm{Cr}$, $\mathrm{Cu}, \mathrm{Pb}$ and $\mathrm{Ni}$ ), chemical and allied products $(\mathrm{Zn})$, electronic and electric equipment $(\mathrm{Pb}, \mathrm{Cd})$, maritime paints and shipyard activities $(\mathrm{Cu}, \mathrm{Zn})$, sewage $(\mathrm{Ag})$, etc. [SañudoWilhelmy and Flegal, 1992; Patterson et al., 1998; Howe and Dobson, 2002; Wang et al., 2003; Tovar-Sánchez et al., 2004], other metals like $\mathrm{Al}, \mathrm{Co}, \mathrm{Fe}$ or $\mathrm{Mn}$ have mainly a lithogenic origin [Peris et al., 2008]. Atmospheric transport represents the dominant pathway for large-scale transport of trace metals (i.e., $\mathrm{Al}, \mathrm{Cd}, \mathrm{Cr}, \mathrm{Cu}, \mathrm{Fe}, \mathrm{Mn}, \mathrm{Ni}, \mathrm{Pb}$ and $\mathrm{Zn}$ ) to the Mediterranean Sea [Guieu et al., 1997; Migon, 2005; Guerzoni and Molinaroli, 2005], as riverine inputs are relatively low at the basin scale [Migon, 1993; Migon et al., 2002; Guerzoni and Molinaroli, 2005]. The episodic inputs of Saharan dust have been recognized as particularly important for the transport and deposition of materials to the Mediterranean Sea [Ridame and Guieu, 2002]. Over the last 20 years dust-rain events, from Saharan origin, have increased remarkably in the western Mediterranean region as a consequence of the intensification of meteorological processes (convective and advective synoptic situations) that promote the transport of aerosols from Africa toward the western Mediterranean [QueredaSala et al., 1996]. An increased deposition of Saharan 


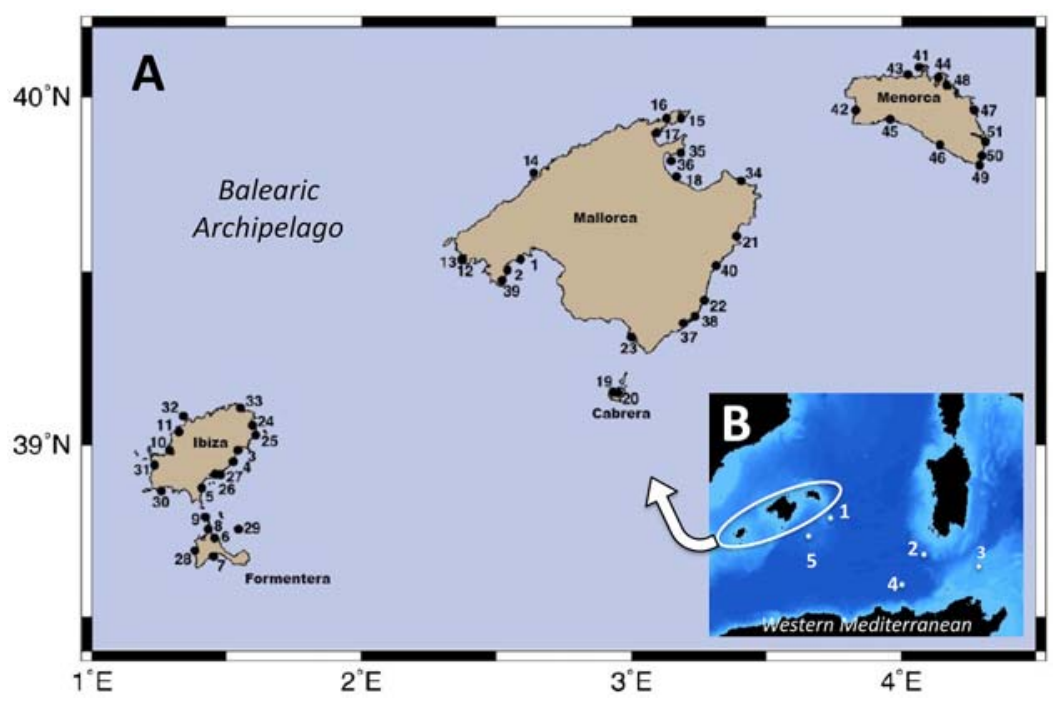

Figure 1. (a) Map of Balearic Archipelago with sampling sites of $P$. oceanica (black dots). (b) Map of the western Mediterranean with sampling sites of suspended aerosols.

dust to the Mediterranean may result in an increase in the input of metals of which Sahara dust is rich and may also become further enriched by scavenging during atmospheric transport (e.g., Al, Cr, Fe, Mn [Guieu et al., 1997, 2002]). Any increase in metal inputs to the Mediterranean Sea should be reflected in an increase in metal concentrations in living organisms. Sessile organisms like plants (e.g., macroalgae [Olgunoglu and Polat, 2008] and seagrasses [Roméo et al., 1995]), should therefore become excellent biological tracers of metal concentrations in the environment.

[4] Posidonia oceanica is a long-lived seagrass species with shoots living for several decades [Marbà et al., 2002], that forms meadows at depths ranging from 1 to $40 \mathrm{~m}$ that extend over a total estimated area of $50,000 \mathrm{~km}^{2}$ in the Mediterranean Sea [Bethoux and Copin-Móntegut, 1986]. It has been well established that $P$. oceanica sequester trace metals from the marine environment and that metal concentrations in their perennial tissues, which remain for decades, can be used as a proxy to trace ambient metal and radionuclide concentrations over long periods of time [Roméo et al., 1995; Pergent-Martini, 1998; Calmet et al., 1988; Baroli et al., 2001; Ancora et al., 2004; Tranchina et al., 2005a, 2005b; Lafabrie et al., 2009]. The growth of $P$. oceanica is highly organized, a regular number of leaves and rhizome internodes being produced at a ratio 1:1 annually at the apical rhizome meristems. Therefore, the age of different rhizomes can be estimated [Duarte et al., 1994]. These findings have highlighted the potential of this seagrass species as a biological indicator of both contamination and environmental variability. Retrospective examination of the long-term variability of elemental composition of plant tissues across regional scales can provide information about the temporal and spatial dynamics of trace metal inputs in the coastal ocean and help discriminate between local and large-scale (e.g., atmospheric) sources.

[5] While several studies have investigated trace metal concentrations in P. oceanica over the Mediterranean [e.g., Baroli et al., 2001; Ancora et al., 2004; Tranchina et al., 2005a], information on metal levels in the Balearic Archi- pelago is very limited. While previous works were very localized and focused to assess the degree of metal pollution in the area, our study was designed to elucidate local and regional processes affecting plant metal concentration. The goal of this study is to examine the changes of trace metal composition in rhizomes of $P$. oceanica along coastal waters of the Balearic Islands, western Mediterranean, over the past 3 decades to identify and evaluate the spatial and temporal trends of metal inputs. Then, we evaluate and discuss the possible link between aeolian input and seagrass chemical composition. Because industrial activity in, and nearby, the Balearic Islands is minimal, any enrichment and/or longterm trend in trace metal concentration in $P$. oceanica rhizomes in this region may derive from local point sources or long-distance transport, particularly atmospheric supply. We, therefore, compared metal enrichment and trends in $P$. oceanica rhizomes with metal concentrations in direct measurements of atmospherically suspended aerosols and long-term dynamics of atmospheric aerosols in the region.

\section{Methods}

[6] The Balearic archipelago (Spain) is located in the western Mediterranean Sea, and it is composed of four major (Mallorca, Menorca, Ibiza and Formentera) and other minor islands (Cabrera and islets) (Figure 1). The Balearic Islands lack significant industrial and riverine inputs and the main human pressure on the coastal water comes from urban activities. Much of the coastal zone is protected (e.g., Minorca Island was declared a Biosphere Reserve in 1993, while Cabrera and small surrounded islets were declared a Spanish national park in 1991). These coastal waters support very extensive $P$. oceanica meadows, growing above ironpoor biogenic carbonate sediments.

[7] Posidonia oceanica was sampled during August 2005 to September 2005 and August 2006 to October 2006 in 51 meadows at 3-18 $\mathrm{m}$ depth along the coast of the Balearic Islands (Figure 1). At each station, SCUBA divers collected up to three old orthotropic (vertically growing) rhizomes 
holding standing leaves. Samples were thoroughly rinsed in ambient seawater, stored in polyethylene bags and frozen. In the laboratory leaves, leaf sheaths and epiphytes were removed from rhizomes. After rinsing with ultrapure water to remove fine sediments particles, rhizomes were carefully cut (using a ceramic knife) in segments of $1 \mathrm{~cm}$ of length, corresponding to 1 lepidochronological year period of growth [Marbà and Duarte, 1997]. Previous studies indicated that average vertical rhizome growth of $P$. oceanica along the Balearic Islands was $8.2 \pm 0.14 \mathrm{~mm} \mathrm{yr}^{-1}$ (N. Marbà and C. M. Duarte, unpublished manuscript, 2010). Each rhizome segment, previously dried at $60^{\circ} \mathrm{C}$ for $24 \mathrm{~h}$ and weighted, was digested in high-pressure Teflon vessels using a mixture of high-purity acids (suprapur, Merck) $\mathrm{HNO}_{3}^{-}(67 \%)+\mathrm{HCl}$ $(13 \%)+$ ultrapure water (20\%) [Duarte et al., 1995]. Digested samples were transferred into acid cleaned polypropylene tubes and diluted 1:4 (v/v) with ultrapure water. Metal concentrations ( $\mathrm{Al}, \mathrm{Ag}, \mathrm{Cd}, \mathrm{Co}, \mathrm{Cr}, \mathrm{Cu}, \mathrm{Fe}, \mathrm{Mn}, \mathrm{Ni}, \mathrm{Pb}$ and $\mathrm{Zn}$ ) were determined by ICP-AES (Perkin Elmer ICP-AES Optima 5300 DV). Procedural blanks were obtained from acid medium as described above for rhizomes. Detection limits, calculated as three times the standard deviation of the blanks values, were in $\mathrm{ng} \mathrm{g}^{-1}: \mathrm{Ag}=0.09, \mathrm{Al}=0.31, \mathrm{Cd}=0.16, \mathrm{Co}=$ $0.15, \mathrm{Cr}=0.19, \mathrm{Cu}=2.96, \mathrm{Fe}=0.50, \mathrm{Mn}=0.01, \mathrm{Ni}=0.54$, $\mathrm{Pb}=0.15$ and $\mathrm{Zn}=1.63$. The accuracy of the analytical procedure was checked using a standard reference material (sea lettuce Ulva lactuca, CRM 279; Community Bureau of Reference) with recoveries ranging from $93 \%$ for $\mathrm{Pb}$ to $104 \%$ for $\mathrm{Ni}$ of certified and indicative values. The trace metal composition during the life span of $P$. oceanica rhizomes (up to 3 decades) was examined for each lepidochronological year (i.e., approximately October to October) in samples from stations 1 to 25 . In other cases (from station 26 to station 51), duplicated or triplicate rhizomes were analyzed in two fractions, one corresponding to the 3 youngest lepidochronological years and the other to the rest of rhizome.

[8] Sampling of aerosol was carried out during a cruise on board the R/V Garcia del CID in June-July 2006 across the Mediterranean Sea. Samples of coarse $(>20 \mu \mathrm{m})$ suspended aerosols were collected at six stations (latitude $\mathrm{N}$-longitude E; station 1: 38.9033-4.8025; station 2: 38.3086-8.0950; station 3: 37.8845-10.6443; station 4: 37.7626-7.3435; station 5: 38.1211-4.5328; Figure 1) onto an acid-washed cellulose filter (Whatman 41) in a high-volume collector (MCV: CAV-A/HF). A microwave acid digestion procedure [Pekney and Davidson, 2005] followed by ICP-AES was used to measure total trace metal levels in those aerosol filters (Al, $\mathrm{Cr}, \mathrm{Fe}, \mathrm{Mn}, \mathrm{Ni}, \mathrm{Pb}, \mathrm{Cu}$, and $\mathrm{Zn}$ ).

[9] The total annual index of atmospheric aerosols was estimated by remote sensing over the Balearic Islands (http://toms.gsfc.nasa.gov/aerosols/aerosols_v8.html). According to the NASA, the Total Ozone Mapping Spectrometer (TOMS) aerosol index is defined as: "a measure of how much the wavelength dependence of backscattered UV radiation from an atmosphere containing aerosols (Mie scattering, Rayleigh scattering, and absorption) differs from that of a pure molecular atmosphere (pure Rayleigh scattering)" (http://toms.gsfc.nasa.gov/aerosols/aerosols_v8.html). This index is related to aerosol optical depth, and indicates the amount of aerosols (e.g., dust, volcanic ash, and smoke) that absorb ultraviolet (UV) radiation in the atmosphere. The aerosol index is calculated daily by using a retrieval algorithm
[Torres et al., 1998, 2002] based on the absorbance measurements (331-360 nm) done by the Earth Probe TOM (Total Ozone Mapping Spectrometer) instrument onboard the Aura satellite system. Because TOMs have been experiencing instrument problems, the aerosol index from 2001 onward should be considered only approximate. Air mass origins for the cruise samples were established using the NOAA Hybrid Single-Particle Lagrangian Integrated Trajectory Model (HYSPLIT) [Draxler and Rolph, 2003].

[10] Because metal concentrations along rhizomes exhibited wide temporal fluctuations, we used median values to characterize the metal composition of each station. Differences in $P$. oceanica metal concentration across islands were statistically tested using Analysis of Variance, and differences between paired islands identified with TukeyKramer test. The magnitude of temporal fluctuations in $P$. oceanica metal concentrations was quantified using the coefficient of variation (CV). Significant temporal shifts in $P$. oceanica metal (e.g., Ag) concentration among islands were tested using $t$ test. We used cross correlation analysis to demonstrate the coupling between average temporal trends in $\mathrm{Zn}$ and $\mathrm{Ni}$ for each island and atmospheric aerosol index despite the existence of time lags in seagrass response. Metal concentrations were calculated with respect to dry weight.

\section{Results}

[11] The length of orthotropic rhizomes studied ranged from 4.5 to $32 \mathrm{~cm}$, which represent between 4 (station 11) and 29 (station 22) years old. Hence metal contents were analyzed in a total of 292 rhizomes sections, the oldest formed in 1976. Median, minimum and maximum metal (Al, Ag, Cd, Co, Cr, Cu, Fe, Mn, Ni, Pb and $\mathrm{Zn}$ ) concentrations in rhizomes collected in 51 meadows around the Balearic Islands (Figure 1) are shown in Table S1 (available as auxiliary material). ${ }^{1}$ The lowest median metal contents characterized Formentera (Al: $1.32 \mu \mathrm{g} \mathrm{g}^{-1}, \mathrm{Cd}: 0.41 \mu \mathrm{g} \mathrm{g}^{-1}$, $\mathrm{Cu}: 4.31 \mu \mathrm{g} \mathrm{g}^{-1}$, Fe: $15.85 \mu \mathrm{g} \mathrm{g}^{-1}$, Mn: $1.30 \mu \mathrm{g} \mathrm{g}^{-1}$ and $\mathrm{Pb}$ : $0.05 \mu \mathrm{g} \mathrm{g}^{-1}$ ) and Ibiza (Cr: $0.01 \mu \mathrm{g} \mathrm{g}^{-1}$, Ni: $0.97 \mu \mathrm{g} \mathrm{g}^{-1}$ and $\left.\mathrm{Zn}: 4.02 \mu \mathrm{g} \mathrm{g}^{-1}\right)$ meadows. Although the lowest concentrations of $\mathrm{Ag}$ and Co were found, occasionally, in rhizomes from stations $17\left(1.24 \mu \mathrm{g} \mathrm{g}^{-1}\right.$, Mallorca) and $42(0.02 \mu \mathrm{g}$ $\mathrm{g}^{-1}$, Menorca), respectively, very low concentrations were also measured in samples from Formentera (e.g., St 7: $2.43 \mu \mathrm{g} \mathrm{g}^{-1} \mathrm{Ag}$ and St 28: $\left.0.04 \mu \mathrm{g} \mathrm{g}^{-1} \mathrm{Co}\right)$. The highest concentrations of $\mathrm{Al}\left(174.73 \mu \mathrm{g} \mathrm{g}^{-1}\right), \mathrm{Cd}\left(3.56 \mu \mathrm{g} \mathrm{g}^{-1}\right), \mathrm{Cr}$ (1.34 $\left.\mu \mathrm{g} \mathrm{g}^{-1}\right), \mathrm{Cu}\left(32.15 \mu \mathrm{g} \mathrm{g}^{-1}\right), \mathrm{Pb}\left(8.51 \mu \mathrm{g} \mathrm{g}^{-1}\right)$ and $\mathrm{Zn}$ $\left(107.14 \mu \mathrm{g} \mathrm{g}^{-1}\right)$ were measured in meadows located around the Mallorca Island. On the other hand, the highest median concentrations of $\mathrm{Ag}\left(27.58 \mu \mathrm{g} \mathrm{g}^{-1}\right), \mathrm{Fe}\left(624.09 \mu \mathrm{g} \mathrm{g}^{-1}\right)$ and Mn $\left(31.66 \mu \mathrm{g} \mathrm{g}^{-1}\right)$ were measured at the north of Menorca Island (station 43).

[12] Except for Al, concentrations of all metals in $P$. oceanica varied significantly among islands (ANOVA with comparisons for all pairs using Tukey-Kramer test; Table S2). Concentrations of $\mathrm{Cu}, \mathrm{Ag}$ and $\mathrm{Mn}$ showed the highest spatial variations (ANOVA and Tukey-Kramer test, $\mathrm{p}<0.001$; Table S2).

\footnotetext{
${ }^{1}$ Auxiliary materials are available in the HTML. doi:10:1029/ 2009JG001076.
} 

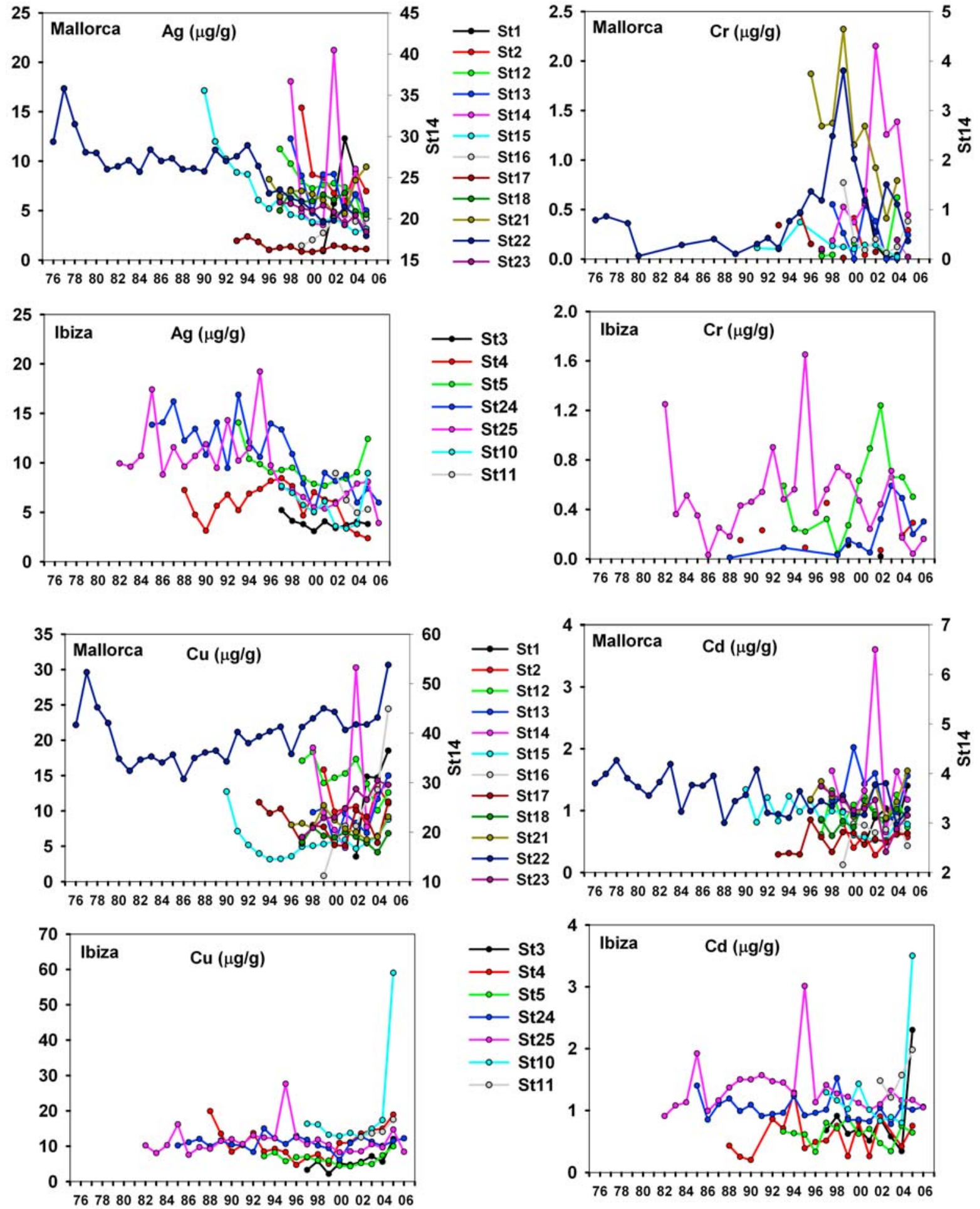

Figure 2. Concentrations, at different stations, of $\mathrm{Ag}, \mathrm{Cr}, \mathrm{Cu}$, and $\mathrm{Cd}$ of $P$. oceanica from the Mallorca and Ibiza islands as a function of lepidochronological years. Concentrations of $\mathrm{Cr}$ at stations 10 and 11 were below detection limit. Note that different scale is used for station 14 .

[13] Interannual fluctuations of metal concentrations in $P$. oceanica rhizomes were broadly variable, CV: Al (19$129 \%)$, Cd (18-69\%), Co (27-140\%), Cr (16-231\%), $\mathrm{Cu}(12-96 \%)$, Fe (26-102\%), Mn (6-71\%), Pb (40-258\%) (Figures 2-4 and Figures S1-S3). After excluding values at station 14 in Mallorca Island, where concentrations were generally higher for almost all analyzed elements, probably due to a local source, the lowest temporal variations in metal concentrations were found around the smallest and less impacted islands, Cabrera (CV: 57, 31, 65 and 55\%, for $\mathrm{Al}, \mathrm{Cd}, \mathrm{Fe}$ and $\mathrm{Mn}$, respectively) and Formentera (CV: 53, $51 \%$ for $\mathrm{Co}$ and $\mathrm{Cu}$, respectively). Only $\mathrm{Cr}(\mathrm{CV}: 85 \%)$ and 

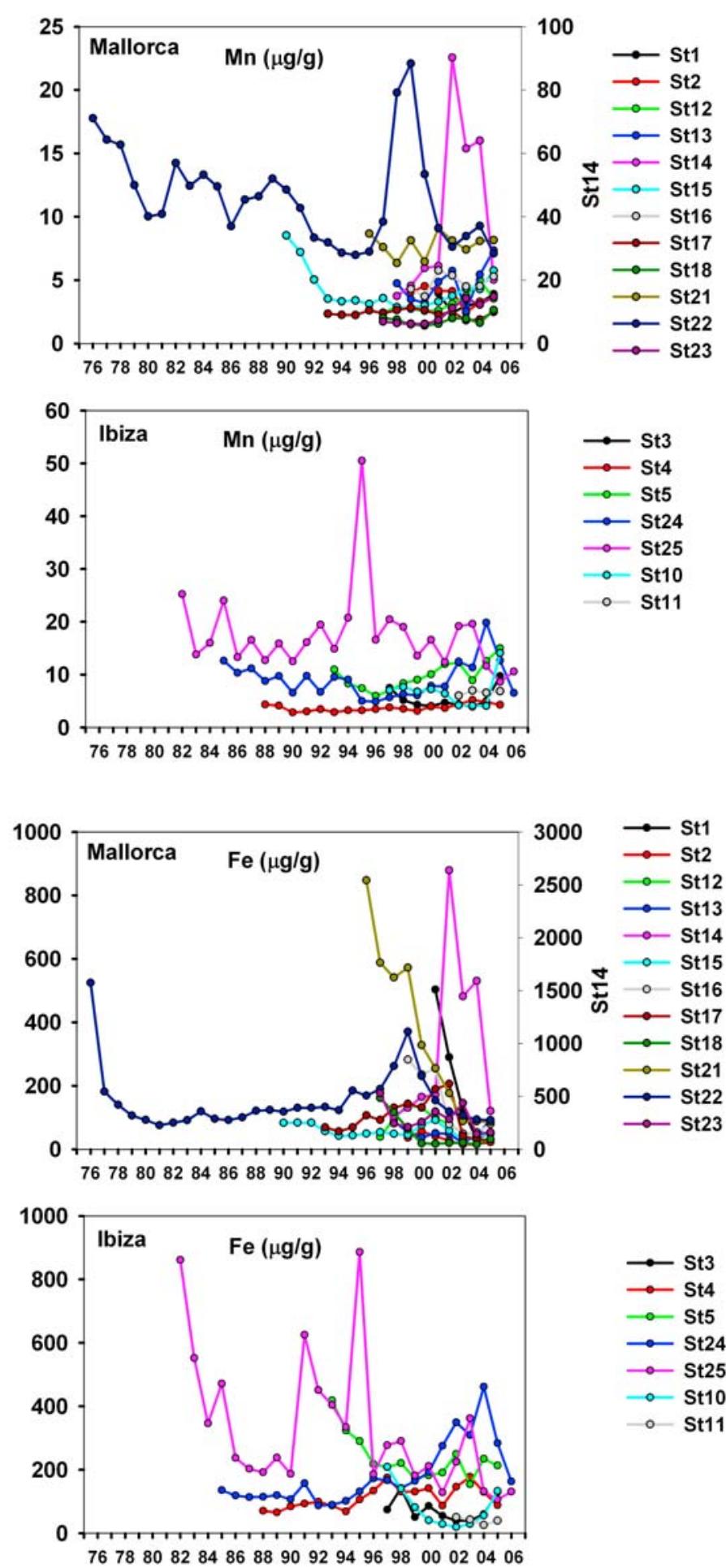
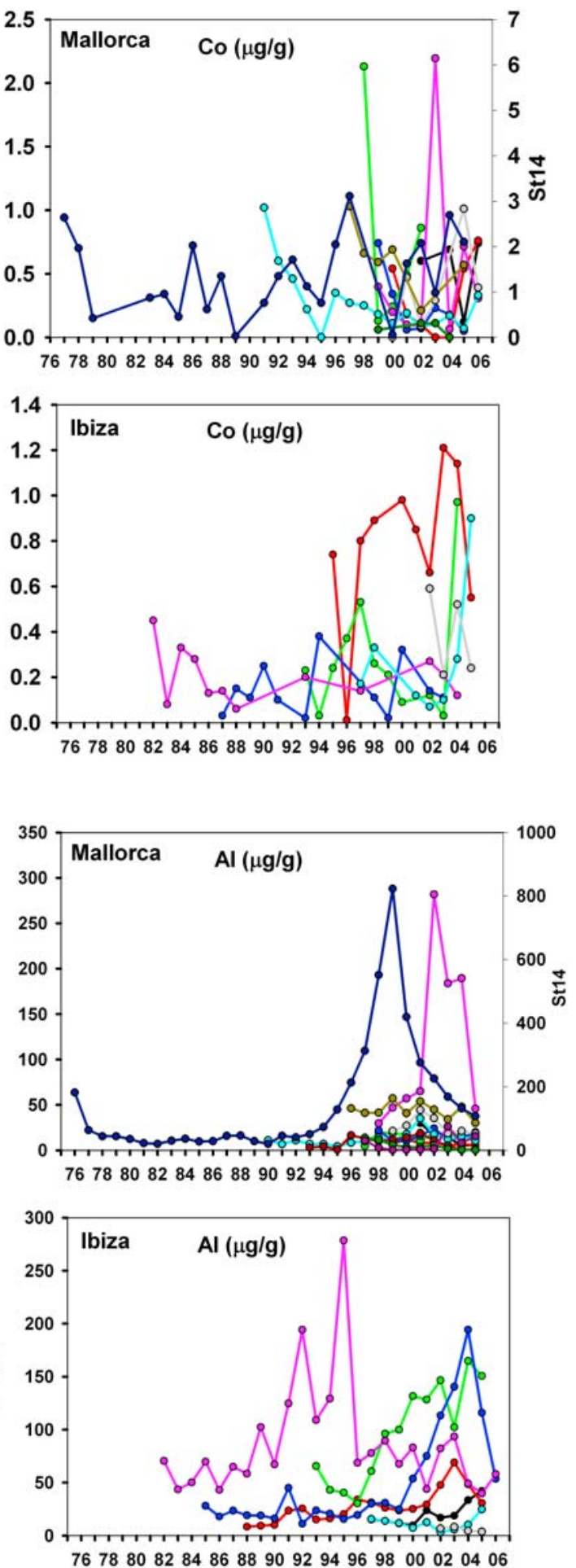

Figure 3. Concentrations, at different stations, of $\mathrm{Mn}, \mathrm{Co}, \mathrm{Fe}$, and $\mathrm{Al}$ of $P$. oceanica from the Mallorca and Ibiza islands as a function of lepidochronological years. Concentrations of $\mathrm{Co}$ at stations 5, 17, and 23 were below detection limit. Note that different scale is used for station 14.

$\mathrm{Pb}(\mathrm{CV}: 69 \%)$ showed the lowest variations at Ibiza and Mallorca, respectively. No temporal trends of these metals concentrations were observed in the studied meadows.

[14] Ag, Ni and $\mathrm{Zn}$ concentrations also showed interannual changes along the rhizomes and variations among different meadows, thus the highest variations of $\mathrm{Ag}(\mathrm{CV}$ : 97\%) were shown at Cabrera, while Ni (CV: 165\%) and Zn (CV: $113 \%$ ) varied greatly at Ibiza Island. A temporal sustained decreasing trend of $\mathrm{Ag}$ concentration was observed in most rhizomes from Mallorca and Ibiza islands since year 

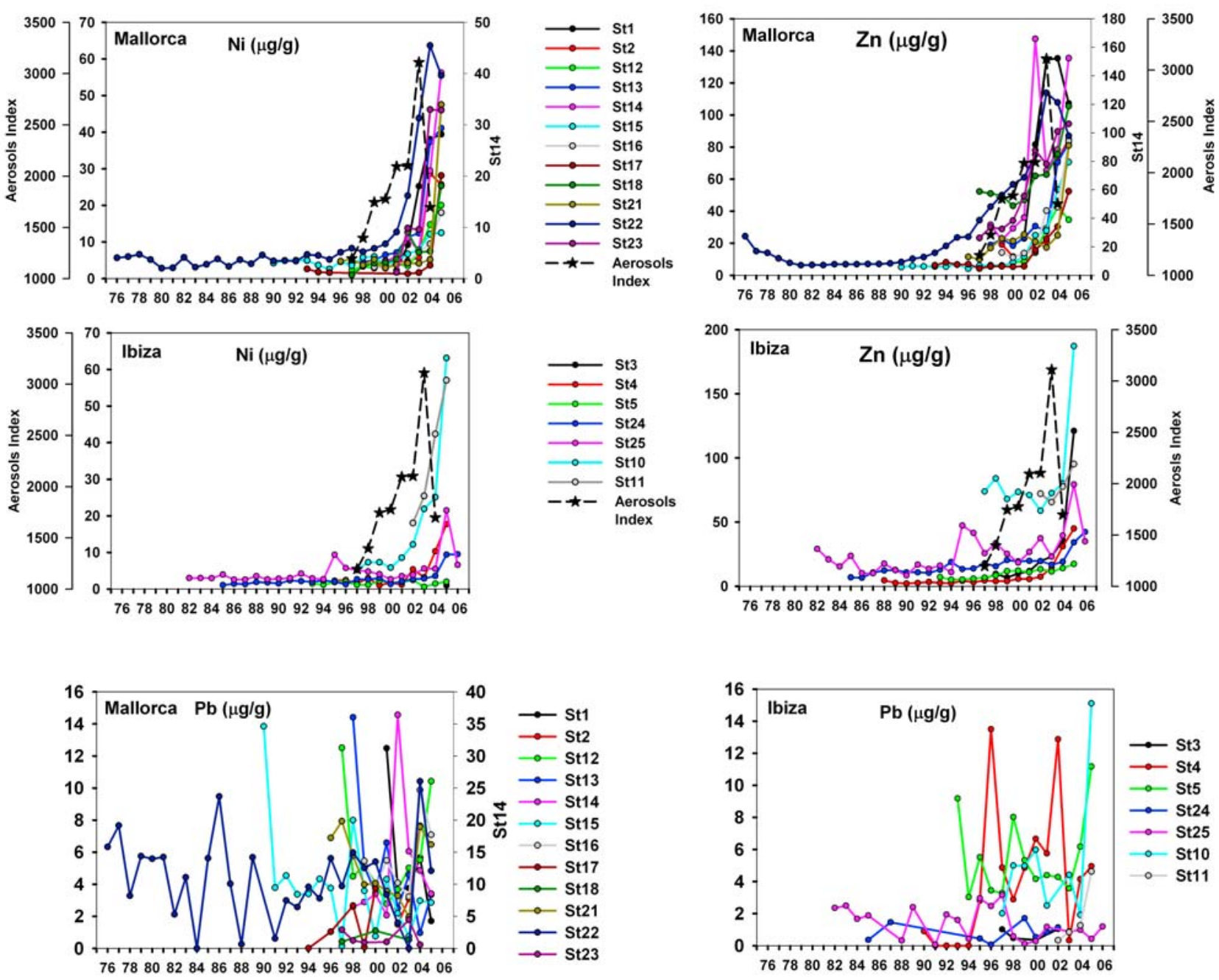

Figure 4. Concentrations, at different stations, of $\mathrm{Ni}, \mathrm{Zn}$, and $\mathrm{Pb}$ of $P$. oceanica from the Mallorca and Ibiza islands as a function of lepidochronological years. Dashed line is the annually aerosols index estimated by satellite on the Balearic Archipelago region. Note that different scale is used for station 14.

1995 (Figures 2 and S1). A $t$ test indicated that Ag contents in the rhizome were significantly lower $(p<0.0001)$ after $1995(5.44 \pm 0.30$ versus $9.75 \pm 0.55$ and $6.66 \pm 0.37$ versus $10.80 \pm 0.49$ at Mallorca and Ibiza, respectively). Conversely, Nickel and $\mathrm{Zn}$ concentrations in all $P$. oceanica rhizomes increased since year 1996 at all studied stations (Figures 4 and S3), although the largest increase was detected since 2000-2002.

\section{Discussion}

\subsection{P. oceanica Trace Metal Characterization in the Balearic Archipelago}

[15] Chemical composition of $P$. oceanica over the Balearic archipelago shows the lowest metal contents in plants from Formentera and Cabrera islands. These islands are the smallest and less inhabited islands of the archipelago and consequently those supporting the least anthropogenic pressure on their coastal system. In contrast, the highest concentrations were measured in meadows located around Mallorca and Menorca islands, the largest and most densely populated islands of the archipelago. The metal enrichment in rhizomes from station 43 (Menorca) cannot easily be attributed to anthropogenic causes since this meadow is located in a marine reserve where no sewage or submarine outfalls were identified.

[16] Mean values of metal concentrations in rhizomes collected in the Balearic Archipelago are in agreement with ranges reported for other areas in the Mediterranean Sea, except for Co whose concentrations $\left(0.22-0.86 \mu \mathrm{g} \mathrm{g}^{-1}\right)$ were 1 order of magnitude lower than reported for other Mediterranean areas (1.7-12.1 $\mathrm{g} \mathrm{g}^{-1}$ ) (Table 1). Iron concentrations were often observed to be below the threshold $\left(100 \mu \mathrm{g} \mathrm{g}^{-1} \mathrm{Fe}\right)$ for iron sufficiency in angiosperms, as expected for carbonate sediments away from anthropogenic Fe inputs [Duarte et al., 1995], thus suggesting that Fe supply may often limit the growth of $P$. oceanica in the Balearic Islands [Holmer et al., 2005; Marbà et al., 2007]. The finding of low $\mathrm{Fe}$ concentration in rhizomes agrees with previous observations relative to leaves of $P$. oceanica from the same region [Fourqurean et al., 2007]. To our knowledge this is the first study that measures $\mathrm{Ag}$ and $\mathrm{Al}$ concentrations in 
$P$. oceanica, therefore comparison with other Mediterranean regions is not possible.

[17] The concentrations of $\mathrm{Al}, \mathrm{Co}, \mathrm{Cr}$ and $\mathrm{Pb}$ in $P$. oceanica rhizomes exhibited the widest interannual fluctuations. The temporal changes in the concentration of these metals in $P$. oceanica rhizomes were not consistent at regional scale (Figures 2-4 and Figures S1-S3). Individual increases of concentrations like those detected for $\mathrm{Al}, \mathrm{Cr}, \mathrm{Fe}$ and $\mathrm{Mn}$ at station 22 in the section of rhizome dated in 1999 (Figures 2 and 3 ), or the higher concentrations of all elements measured along the rhizome of station 14 , could be due to local, point source contamination from undetected or uncontrolled sewages or shipyard activities.

[18] Concentrations of some metals (i.e., Ag, Ni and $\mathrm{Zn}$ ) in $P$. oceanica rhizomes showed consistent temporal trends. Thus, while Ag concentration decrease with time from 1990 to $2005, \mathrm{Zn}$ and $\mathrm{Ni}$ increased their concentrations since year 1996 at all studied stations. The major sources of Ag in the environment are waste from human activities (mainly from the photographic industry and photo-processing wastes in sewage sludge), and sewages outfalls have been considered the principal source of anthropogenic silver in coastal water [Sañudo-Wilhelmy and Flegal, 1992; Howe and Dobson, 2002; Wang et al., 2003; Tovar-Sánchez et al., 2004]. The decrease of Ag content in rhizomes of $P$. oceanica observed during the last decades could reflect the decrease of $\mathrm{Ag}$ inputs to the environment as a consequence of the progressive reduction in the use of photographic films caused by the development of digital technology.

[19] The quasi-synoptic increase in $\mathrm{Ni}$ and $\mathrm{Zn}$ concentrations in meadows across the Balearic Islands cannot be explained by local inputs. Indeed, only changes in the atmospheric deposition of these elements with aerosols could possibly explain this marked and synoptic trend in plants across such a large area. To test the hypothesis that $\mathrm{Ni}$ and $\mathrm{Zn}$ composition of $P$. oceanica reflects atmospheric deposition, we examined the relationship between the total annual index (from 1997 to 2004) of atmosphere aerosols estimated daily by remote sensing over the Balearic Islands (http://toms.gsfc.nasa.gov/aerosols/aerosols_v8.html) and the $\mathrm{Ni}$ and $\mathrm{Zn}$ composition of $P$. oceanica (Figures 4 and S3). Remarkably similar trends were observed between the suspended particles in the air and the $\mathrm{Ni}$ and $\mathrm{Zn}$ content in rhizomes, suggesting that the increasing $\mathrm{Zn}$ and $\mathrm{Ni}$ concentrations in $P$. oceanica result from inputs associated with aerosols deposition. Actually, the average annual concentration of $\mathrm{Ni}$ and $\mathrm{Zn}$ in $P$. oceanica rhizomes measured at each island, but Ibiza, was significantly positively correlated with the total atmospheric annual index recorded 3 years before (cross-correlation analysis, $\mathrm{p}<0.05$; Table S3). The best correlations were obtained for $\mathrm{Zn}\left(\mathrm{r}^{2}: 0.78, \mathrm{p}<0.01\right)$ and $\mathrm{Ni}\left(\mathrm{r}^{2}: 0.85, \mathrm{p}<0.05\right)$, at Mallorca and Cabrera, respectively. The fact that metal concentration in $P$. oceanica rhizomes was measured during lepidochronological years (October to October) while atmospheric index was estimated for chronological years (January to January), and the slow growth of this seagrass species might explain the time lag observed in $P$. oceanica metal concentration response. An increasing trend of $\mathrm{Zn}$ concentration in $P$. oceanica rhizomes between years 1990 and 1999 was also reported in a different area of the Mediterranean (Gulf of Naples, Italy [Ancora et al., 2004]). Although in this study the sources were not 


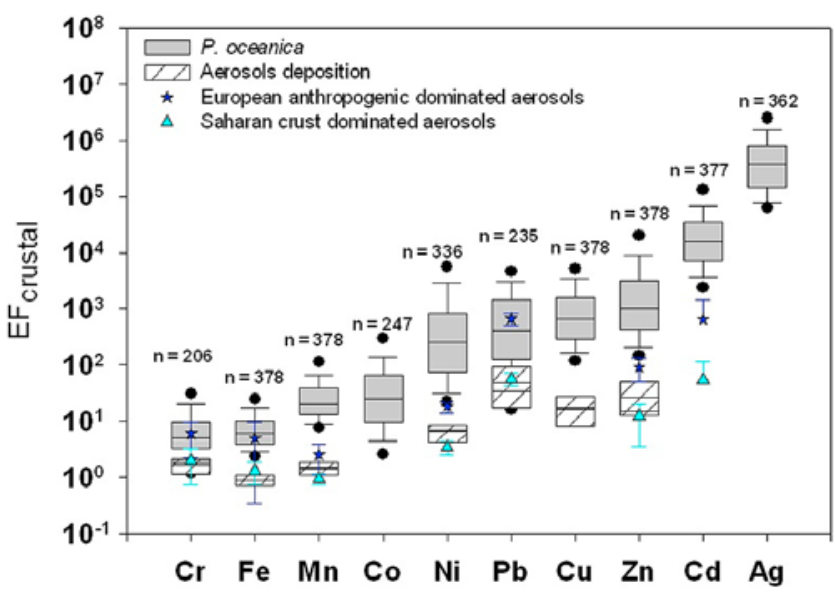

Figure 5. Crustal enrichment factor (EF crustal) for elements in the rizhomes of $P$. oceanica over all islands of the Balearic Archipelago (solid boxes), in suspended aerosols on the western Mediterranean (dashed boxes), and in European anthropogenic and crustal dominated aerosols on the Mediterranean (stars and triangles, respectively) [Guerzoni et al., 1999]. The line within the box is the median, and the error bars indicate the 5 th and 95 th percentiles. Solid circles show outlying points, and $\mathrm{n}$ is the number of $\mathrm{EF}_{\text {crustal }}$ values for rizhomes of $P$. oceanica.

indentified, our results indicate a wide regional influence of aerosols depositions on the $\mathrm{Zn}$ composition of $P$. oceanica.

\subsection{Natural and Anthropogenic Contribution}

[20] The metal concentrations normalized to a crustal reference (i.e., $\mathrm{Al}$ ) are usually used to estimate the relative contributions of anthropogenic and natural sources. Thus, in order to estimate the degree to which the trace metals measured in $P$. oceanica are enriched relative to putative aerosols sources we calculated the crustal enrichment factor $\left(\mathrm{EF}_{\text {crustal }}\right)$ following the equation [Taylor, 1964; Ikegawa et al., 1999]:

$$
\mathrm{EF}_{\text {crustal }}=(\mathrm{Me} / \mathrm{Al})_{\text {P.oceanica }} /(\mathrm{Me} / \mathrm{Al})_{\text {crust }} ;
$$

where $\mathrm{Me}$ and $\mathrm{Al}$ are the concentrations of each studied metal and $\mathrm{Al}$, in $P$. oceanica and in average crustal material, respectively. By convention, average $\mathrm{EF}_{\text {crustal values of any }}$ element $<10$ suggest that crustal material, derived in this case from the Sahara desert, is the probably source for that element [Duce et al., 1975; Ikegawa et al., 1999; Chester et al., 1999]. We are aware that $\mathrm{EF}_{\text {crustal }}$ is mostly applicable to mineral matter. Although, in this case we assume that the uptake and dissolution processes, of many elements in $P$. oceanica, are congruent with the dissolution and uptake of the reference element (i.e., Al). This assumption is supported by the use of this plant as a proxy to trace ambient metal concentration [e.g., Roméo et al., 1995; Pergent-Martini, 1998; Baroli et al., 2001; Tranchina et al., 2005a]. $\mathrm{EF}_{\text {crustal }}$ values suggest that $\mathrm{Cr}$ (median: 5.0) and $\mathrm{Fe}$ (median: 5.8) in rhizomes of $P$. oceanica from the Balearic Islands are likely derived from a crustal source (Figure 5). The other elements showed slightly (median values for $\mathrm{Mn}: 20.3$ and $\mathrm{Co}: 22.9$ ) or higher $(\mathrm{Ni}>\mathrm{Pb}>\mathrm{Cu}>\mathrm{Zn}>\mathrm{Cd}>\mathrm{Ag})$ values, indicating that they are enriched relative to crustal sources. In order to evaluate the connection between aeolian input and $P$. oceanica chemical composition, we measured the chemical composition of collected aerosols suspended particles in the western Mediterranean (Figure 1). Concentrations of $\mathrm{Al}, \mathrm{Cr}, \mathrm{Cu}, \mathrm{Fe}, \mathrm{Mn}$, $\mathrm{Ni}, \mathrm{Pb}$ and $\mathrm{Zn}$, in the aerosols were $279.8-1403.5,0.6-2.3$, 2.6-19.4, 147.7-814.8, 5.1-25.8, 2.0-7.0, 1.2-6.0, and 11.0 $14.9 \mathrm{ng} / \mathrm{m}^{3}$, respectively.

[21] A comparison of the $\mathrm{EF}_{\text {crustal }}$ calculated for $P$. oceanica with that of aerosols collected in this work, and those reported for anthropogenic and Saharan dominated aerosols in the Mediterranean [Guerzoni et al., 1999] indicate that $\mathrm{Pb}, \mathrm{Ni}, \mathrm{Zn}$ and $\mathrm{Cd}$ are more clearly influenced by aerosols with an anthropogenic component than by a Saharan component (Figure 5). To support this statement, we have estimated the air mass origins for our suspended aerosols samples using the NOAA Hybrid Single-Particle Lagrangian Integrated Trajectory Model (HYSPLIT) [Draxler and Rolph, 2003] (Figure S4). The back trajectories (for the $48 \mathrm{~h}$ preceding sample collections) indicate that aerosols particles collected during our sampling date come from northwestern Europe, and therefore they probably have an anthropogenic load. On the other hand, the ratios of these metals to $\mathrm{Al}$ in aerosols were, except for $\mathrm{Pb}$, lower than those in the plants (Figure 5), which suggest the presence of local sources of these metals enriching $P$. oceanica tissues. Lead from anthropogenic European aerosols clustered with $\mathrm{Pb}$ composition of $P$ oceanica, suggesting that these aerosols might also be a source.

[22] As indicated above, the coupling between temporal variations in $\mathrm{Ni}$ and $\mathrm{Zn}$ concentrations along Posidonia rhizomes and the annual record of suspended particles in the air point out an influence of aerosol deposition on the composition of $P$. oceanica (Figures 4 and S3). However, the observation that the concentration of these two elements in $P$. oceanica cannot be explained by a normal crust event and the fact that other elements of crustal origin (e.g., Fe, $\mathrm{Mn})$ do not show the same temporal trend as aerosols records represents apparently a paradox. This could be explained by (1) total $\mathrm{Ni}$ and $\mathrm{Zn}$ concentrations in aerosol deposition at the northwestern Mediterranean are higher than those expected regarding the $\mathrm{EF}_{\text {crust }}$ [Guieu et al., 1997]. Although the causes are not yet known, additional sources of $\mathrm{Zn}$ to the Mediterranean (from local or regional anthropogenic origin), or underestimation of aerosols concentration (e.g., significant gaseous contribution) have been suggested [Migon, 2005; Guieu et al., 1997]. In fact, the Ni and $\mathrm{Zn}$ EF values of European anthropogenic dominated aerosols reported by Guerzoni et al. [1999] and plotted in Figure 5 were only 1 order of magnitude lower (Ni: 15-21 and $\mathrm{Zn}:$ 63-120) than those calculated for $P$. oceanica (median and range: 251.5 and $6.5-6.710^{5}$ for $\mathrm{Ni}, 1001.6$ and $81.8-15.810^{5}$ for $\mathrm{Zn}$ ), supporting this possibility; (2) differential translocation, use and storage of trace metals in seagrass organs, as some metals, such as Fe, may play a key role as limiting element and be translocated from rhizomes to leaves and used to produce new plant tissues, whereas some others, in excess of biological demand or with no biological function, may remain in the rhizomes; and (3) our aerosols EF calculation might be underestimated since we used filters of big pore size (Whatmann 41) which collect only large suspended aerosols particles $(>20 \mu \mathrm{m})$. 
The small aerosols fraction $(<20 \mu \mathrm{m})$ could contribute significantly to the total atmospheric deposition and could even have a different chemical composition.

[23] Although aerosol deposition in the Mediterranean Sea has increased since 1996, concentrations of lithogenic elements (i.e., $\mathrm{Fe}$ and $\mathrm{Mn}$ ) in $P$. oceanica rhizomes do not exhibit an increasing trend. Posidonia in the Balearic Islands grows on carbonate-rich and iron-poor sediments and it is iron deficient, as demonstrated by Fe-addition experiments [Holmer et al., 2005; Marbà et al., 2007]. Iron additions to $P$. oceanica meadows enhance clonal growth and, thus, production of new shoots, without increasing Fe concentrations in plant tissues [Marbà et al., 2007]. Therefore, the growth response to increased $\mathrm{Fe}$ inputs is expected to dilute the concentration possibly accounting for the lack of increase of Fe concentrations in P. oceanica meadows in the Balearic Island compared to the increase in aerosol deposition since 1996. An increased Fe deposition to the region, from increased atmospheric dust transport, may have improved the condition of $P$. oceanica meadows in the region, as $\mathrm{Fe}$ inputs have been experimentally shown to reduce seagrass population decline in the Balearic Islands [Marbà et al., 2007]. Manganese is also a micronutrient essential for plant growth [Barker and Pilbeam, 2006]; however, there is no information on the nutritional status of $P$. oceanica relative to this element. Some trace metals $(\mathrm{Zn}$, $\mathrm{Cd}, \mathrm{Mn}$ and $\mathrm{Ni}$ ) can be mobilized within plants, such wheat, toward new growing leaves [Page and Feller, 2005]. Therefore, an increase of $\mathrm{Zn}$ and $\mathrm{Ni}$ in $P$. oceanica rhizomes during the recent years could be an artifact derived from translocation toward rhizome meristem, i.e., recently produced rhizome segments. Yet, if this was indeed the cause, a greater increase would be expected for $\mathrm{Fe}$, the main limiting trace element to $P$. oceanica in these waters [Holmer et al., 2005; Marbà et al., 2007], whereas no such trend was observed. Moreover, increasing trends were observed at the same time (1996) in both young and old rhizomes, further indicating the influence of an external cause. Hence, our results suggest that aerosols deposition may have been the main source of $\mathrm{Zn}$ and $\mathrm{Ni}$ to $\mathrm{P}$. oceanica rhizomes in the Balearic Islands over the last 2 decades.

\section{Conclusion}

[24] Our results show that metal concentrations vary few orders of magnitude within $P$. oceanica rhizomes across the Balearic Islands. In addition, metal concentrations show also large, order-of-magnitude temporal variability within any meadow, indicating that the balance between metal supply and, for the essential elements, plant incorporation and allocation patterns can vary greatly. Whereas the internal dynamics of metal mobilization within the plants may play an important role in the variability of some essential metals, such as $\mathrm{Fe}$ and $\mathrm{Co}$, for some others (e.g., Ag) the anthropogenic activity might represent the main cause of variability. Temporal changes in metal concentrations appear to be caused, in the case of $\mathrm{Ni}$ and $\mathrm{Zn}$, by changes in atmospheric inputs, driven by a recent increase in the load of events over the Mediterranean. A comparison of the $\mathrm{EF}_{\text {crustal }}$ calculated for atmospheric aerosols collected over the W Mediterranean Sea and for the seagrass rhizomes reveals an anthropogenic influence for some metals (i.e., $\mathrm{Ni}, \mathrm{Pb}, \mathrm{Cu}$,
$\mathrm{Zn}$ and $\mathrm{Cd}$ ). Atmospheric inputs appear to be the dominant source of Fe to these seagrass meadows, which are strongly Fe-limited, in agreement with the observation that nitrogen in the tissues of these Posidonia oceanica meadows is also predominantly of atmospheric origin [Papadimitriou et al., 2005]. These observations evidence on the importance of atmospheric inputs for the functioning and health of seagrass meadows around the Mediterranean Sea. Moreover, our results clearly indicate that metal concentrations in $P$. oceanica provide a convenient record of metal changes in the environment, enhancing the value of this plant as an indicator of the past and present environmental conditions in the coastal Mediterranean Sea.

[25] Acknowledgments. This research was funded by the Balearic Government, as part of the assessment of Balearic Islands water masses within the European Water Frame Directive, the BBVA Foundation (BIOCON 04-091/05), the European project WISER, and the Cabiarca project (27/2007) funded by the CSIC. We thank R. Martínez, R. Santiago, and N. Garcias-Bonet for assistance with sample collection, and J. F. González (Serveis Cientificotècnics, UIB) for technical support with the ICP. J. Serón was supported by a Javier Benedí-IMEDEA scholarship.

\section{References}

Ancora, S., N. Bianchi, A. Butini, M. C. Buia, M. C. Gambi, and C. Leonzio (2004), Posidonia oceanica as a biomonitor of trace elements in the Gulf of Napoles: Temporal trends by lepidochronology, Environ. Toxicol. Chem., 23(5), 1093-1099, doi:10.1897/02-590.

Barker, A. V., and D. J. Pilbeam (2006), Handbook of Plant Nutrition, 613 pp., CRC Press, Boca Raton, Fla.

Baroli, M., A. Christin, A. Cosse, G. De Falco, V. Gazal, and G. PergentMartini (2001), Concentrations of trace metals (Cd, Cu, Fe, Pb) in Posidonia oceanica seagrass of Liscia Bay, Sardinia (Italy), in Mediterranean Ecosystems: Structures and Processes, edited by F. M. Faranda, L. Guglielmo, and G. Spezie, Springer, New York.

Bethoux, J. P., and G. Copin-Móntegut (1986), Biological fixation of atmospheric nitrogen in the Mediterranean Sea, Limnol. Oceanogr., 31 1353-1358.

Calmet, D., C. F. Boudouresque, and A. Meinesz (1988), Memorization of nuclear atmospheric tests by rhizomes and scales of the Mediterranean seagrass Posidonia oceanica (Linnaeus) Delile, Aquat. Bot., 30(4), 279-294, doi:10.1016/0304-3770(88)90061-7.

Chester, R., M. Nimmo, and M. R. Preston (1999), The trace metal chemistry of atmospheric dry deposition samples collected at Cap Ferrat: A coastal site in the western Mediterranean, Mar. Chem., 68, 15-30, doi:10.1016/S0304-4203(99)00062-6.

Draxler, R. R., and G. D. Rolph (2003), HYSPLIT (HYbrid Single-Particle Lagrangian Integrated Trajectory) model, NOAA Air Resour. Lab. Silver Spring, Md. (Available at http://www.arl.noaa.gov/ready/hysplit4. html).

Duarte, C. M., et al. (1994), Reconstruction of seagrass dynamics: Age determinations and associated tools for the seagrass ecologist, Mar. Ecol. Prog. Ser., 107, 195-209, doi:10.3354/meps107195.

Duarte, C. M., M. Merino, and M. Gallegos (1995), Evidence of iron deficiency in seagrass growing above carbonate sediments, Limnol. Oceanogr., 40(95), 1153-1158

Duce, R. A., G. L. Hoffman, and W. H. Zoller (1975), Atmospheric trace metals at remote Northern and Southern Hemisphere sites: Pollution or natural?, Science, 187, 59-61, doi:10.1126/science.187.4171.59.

Fourqurean, J. W., N. Marbà, C. M. Duarte, E. Diaz-Almela, and S. RuizHalpern (2007), Spatial and temporal variation in the elemental and stable isotopic content of the seagrasses Posidonia oceanica and Cymodocea nodosa from the Illes Balears, Spain, Mar. Biol. Berlin, 151, 219-232, doi:10.1007/s00227-006-0473-3.

Fraústo da Silva, J. J. R., and R. J. P. Williams (1991), The Biological Chemistry of the Elements-The Inorganic Chemistry of Life, Clarendon, Oxford, U. K.

Guerzoni, S., and E. Molinaroli (2005), Input of various chemicals transported by Saharan dust and depositing at the sea surface in the Mediterranean Sea, in The Handbook of Environmental Chemistry, part 5K, pp. 237-268, Springer, Berlin. 
Guerzoni, S., et al. (1999), The role of atmospheric deposition in the biogeochemistry of the Mediterranean Sea, Prog. Oceanogr., 44, 147190, doi:10.1016/S0079-6611(99)00024-5.

Guieu, C., R. Chester, M. Nimmo, J.-M. Martin, S. Guerzoni, E. Nicolas, J. Mateu, and S. Keyse (1997), Atmospheric input of dissolved and particulate metals to the northwestern Mediterranean, Deep Sea Res., Part II, 44, 655-674, doi:10.1016/S0967-0645(97)88508-6.

Guieu, C., M.-D. Loÿe-Pilot, C. Ridame, and C. Thomas (2002), Chemica characterization of the Saharan dust end-member: Some biogeochemical implications for the western Mediterranean Sea, J. Geophys. Res., 107 (D15), 4258, doi:10.1029/2001JD000582.

Holmer, M., C. M. Duarte, and N. Marbà (2005), Iron additions reduce sulfate reduction rates and improve seagrass growth on organic-enriched carbonate sediments, Ecosystems, 8, 721-730, doi:10.1007/s10021-0030180-6.

Howe, P. D., and S. Dobson (2002), Silver and silver compounds: Environmental aspects, in Concise International Chemical Assessment Document, Rep. 44, Int. Programme on Chem. Safety, Geneva. (Available at http://www.inchem.org/documents/cicads/cicads/cicad44.htm)

Ikegawa, M., M. Kimura, K. Honda, I. Akabane, K. Makita, H. Motoyama, Y. Fujii, and Y. Itokawa (1999), Geographical variations of major and trace elements in east Antarctica, Atmos. Environ., 33, 1457-1467, doi:10.1016/S1352-2310(98)00243-X.

Lafabrie, C., G. Pergent, R. Kantin, C. Pergent-Martini, and J.-L. Gonzalez (2007), Trace metals assessment in water, sediment, mussel and seagrass species - Validation of the use of Posidonia oceanica as a metal biomonitor, Chemosphere, 68, 2033-2039, doi:10.1016/j.chemosphere.2007.02.039.

Lafabrie, C., G. Pergenta, and C. Pergent-Martinia (2009), Utilization of the seagrass Posidonia oceanica to evaluate the spatial dispersion of metal contamination, Sci. Total Environ., 407, 2440-2446, doi:10.1016/j.scitotenv.2008.11.001.

Marbà, N., and C. M. Duarte (1997), Interannual changes in seagrass (Posidonia oceanica) growth and environmental change in the Spanish Mediterranean littoral zone, Limnol. Oceanogr., 42(5), 800-810.

Marbà, N., C. M. Duarte, M. Holmer, R. Martínez, G. Basterretxea, A. Orfila A. Jordi, and J. Tintoré (2002), Assessing the effectiveness of protection on Posidonia oceanica populations in the Cabrera National Park (Spain), Environ. Conserv., 29, 509-518, doi:10.1017/S037689290200036X.

Marbà, N., M. L. Calleja, C. M. Duarte, E. Alvarez, E. Díaz-Almela, and M. Holmer (2007), Iron additions reduce sulfide intrusion and reverse seagrass (Posidonia oceanica) decline in carbonate sediments, Ecosystems, 10, 745-756, doi:10.1007/s10021-007-9053-8.

Migon, C. (1993), Riverine and atmospheric inputs of heavy metals to the Ligurian Sea, Sci. Total Environ., 138, 289-299, doi:10.1016/0048-9697 (93)90422-3.

Migon, C. (2005), Trace metals in the Mediterranean Sea, in The Handbook of Environmental Chemistry, part $5 \mathrm{~K}$, Springer, Berlin.

Migon, C., V. Sandroni, J.-C. Marty, B. Gasser, and J.-C. Miquel (2002), Transfer of atmospheric matter through the euphotic layer in the northwestern Mediterranean: Seasonal pattern and driven forces, Deep Sea Res., Part II, 49, 2125-2141, doi:10.1016/S0967-0645(02)00031-0.

Morel, F. M. M., and N. M. Price (2003), The biogeochemical cycles of trace metals in the oceans, Science, 300, 944-947, doi:10.1126/ science. 1083545 .

Olgunoglu, M. P., and S. Polat (2008), Trace metals in marine macroalgae samples from the Iskenderun Bay, Turkey, Fresen Environ Bull., 17, 589-595.

Page, V. U., and R. S. Feller (2005), Selective transport of zinc, manganese, nickel, cobalt and cadmium in the root system and transfer to the leaves in young wheat plants, Ann. Bot., 96, 425-434, doi:10.1093/ aob/mci189.

Papadimitriou, S., H. Kennedy, D. P. Kennedy, C. M. Duarte, and N. Marbá (2005), Sources of organic matter in seagrass-colonized sediments: A sta- ble isotope study of the silt and clay fraction from Posidonia oceanica meadows in the western Mediterranean, Org. Geochem., 36, 949-961, doi:10.1016/j.orggeochem.2004.12.002.

Patterson, J. W., R. A. Minear, E. Gasca, and C. Petropoulou (1998), Industrial discharges of metals to water, in Metals in Surface Waters, edited by H. E. Allen, A. W. Garrison, and G. W. Luther III, pp. 37-65, Ann Arbor Press, Chelsea, Mich.

Pekney, N. J., and C. I. Davidson (2005), Determination of trace elements in ambient aerosol samples, Anal. Chim. Acta, 540, 269-277, doi:10.1016/j.aca.2005.03.065

Pergent-Martini, C. (1998), Posidonia oceanica: A biological indicator of past and present mercury contamination, Mar. Environ. Res., 45(2), 101, doi:10.1016/S0141-1136(97)00023-8.

Peris, M., L. Recatalá, C. Micó, R. Sánchez, and J. Sánchez (2008), Increasing the knowledge of heavy metal contents and sources in agricultural soils of the European Mediterranean region, Water Air Soil Pollut. 192, 25-37, doi:10.1007/s11270-008-9631-1.

Quereda-Sala, J., J. Olcina-Cantos, and E. Montón-Chiva (1996), Red dust rain within the Spanish Mediterranean area, Clim. Change, 32, 215-228, doi:10.1007/BF00143711.

Ridame, C., and C. Guieu (2002), Saharan input of phosphate to the oligotrophic water of the open western Mediterranean Sea, Limnol. Oceanogr., 47(3), 856-869.

Roméo, M., M. Gnassia-Barelli, T. Juhel, and A. Meisnesz (1995), Memorisation of heavy metals by scales of the seagrass Posidonia oceanica, collected in the NW Mediterranean, Mar. Ecol. Prog. Ser., 120, 211-218, doi:10.3354/meps120211.

Sañudo-Wilhelmy, S. A., and A. R. Flegal (1992), Anthropogenic silver in the southern California bight: A new tracer of sewage in coastal waters, Environ. Sci. Technol., 26, 2147-2151, doi:10.1021/es00035a012.

Taylor, S. R. (1964), Abundance of chemical elements in the continental crust: A new table, Geochim. Cosmochim. Acta, 28, 1273-1285, doi:10.1016/0016-7037(64)90129-2.

Torres, O., P. K. Bhartia, J. R. Herman, and Z. Ahmad (1998), Derivation of aerosol properties from satellite measurements of backscattered ultraviolet radiation: Theoretical basis, J. Geophys. Res., 103(D14), 17,09917,110, doi:10.1029/98JD00900.

Torres, O., P. K. Bhartia, J. R. Herman, A. Sinyuk, and B. Holben (2002), A long term record of aerosol optical thickness from TOMS observations and comparison to AERONET measurements, J. Atmos. Sci., 59, 398 413, doi:10.1175/1520-0469(2002)059<0398:ALTROA>2.0.CO;2.

Tovar-Sánchez, A., S. A. Sañudo-Wilhelm, and A. R. Flegal (2004), Temporal and spatial variations in the biogeochemical cycling of cobalt in two urban estuaries: Hudson River Estuary and San Francisco Bay, Estuarine Coastal Shelf Sci., 60, 717-728, doi:10.1016/j.ecss.2004.03.010.

Tranchina, L., M. Brai, F. D’Agostino, A. Bartolotta, and G. Rizzo (2005a), Trace metal in "Posidonia oceanica" seagrass from south-eastern Sicily, Chem. Ecol., 21(2), 109-118, doi:10.1080/02757540500092990.

Tranchina, L., S. Miccichè, A. Bartolotta, M. Brai, and R. N. Mantegna (2005b), Posidonia oceanica as a historical monitor device of lead concentration in marine environment, Environ. Sci. Technol., 39, 30063012, doi:10.1021/es048870u.

Wang, J., C. P. Huang, and D. Pirestani (2003), Interactions of silver with wastewater constituents, Water Res., 37, 4444-4452, doi:10.1016/S00431354(03)00407-X.

J. M. Arrieta, C. M. Duarte, N. Marbà, J. Serón, and A. Tovar-Sánchez, Department of Global Change Research, Instituto Mediterráneo de Estudios Avanzados, Miquel Marqués 21, E-07190 Esporles, Spain. (atovar@ imedea.uib-csic.es) 